\title{
Transpormation Leadership Based on Local Wisdom in the Multiple Intelligences and the Efforts to Overcome Digital Gap
}

\author{
Ahmad Muhibbin ${ }^{1}$, Achmad Fatoni ${ }^{2}$, Obby Taufik Hidayat ${ }^{3}$, Zainal Arifin ${ }^{4}$ \\ Universitas Muhammadiyah Surakarta \\ 19am215@ums.ac.id, ${ }^{2} a f 267 @ u m s . a c . i d,{ }^{3}$ oth785@ums.ac.id,,za135@ums.ac.id
}

\begin{abstract}
This research aims to describe transformational leadership in local wisdom, the development of multiple intelligence, and the efforts to overcome digital inequality in schools. This research uses a qualitative approach. This research was conducted at SD Muhammadiyah 1 Surakarta, under natural conditions. This research uses a case study design. Research data sources are principals, teachers, employees, and students. Research Results: 1) Principal's leadership meets all transformational leadership indicators, characterized by: Idealized Influenced; Inspirational Motivation; Intellectual Stimulation; Individualized Consideration that applies the principles of local wisdom. 2) Transformational leadership in developing multiple intelligence includes: Word Smart, Number smart, Picture Smart, Body Smart, Music Smart, People Smart, Self Smart, Nature Smart. 3) Transformational leadership in overcoming digital divide includes gaps: between teachers, between education staff, between teachers and education staff, between leaders, between leaders and teachers, between leaders and education staff, between students, between students and teachers, between students and staff education.
\end{abstract}

Keywords: transformational leadership, local wisdom, multiple intelligences, digital divide

\section{Introduction}

The dynamics of education will never be finished to be discussed. This interest is an effort to improve the quality of education in Indonesia and even in the world, however, there are various challenges faced in the world of education, one of which is the low leadership skills and digital literacy in responding to the industrial revolution 4.0. Several facts state that the low quality of leadership skills in students is due to the less than optimal form of school principal leadership in terms of curriculum development, cost efficiency of school budgets, and school management [1]. On the other hand there are still some teachers in schools who show their indiscipline in carrying out their duties, the low quality of teachers in teaching, the lack of teachers' ability to manage learning, and the slow teaching staff and administration in serving student needs make students lose good role models in developing leadership skills[24]. In addition, it is related to the digital divide due to low digital literacy which causes the capacity of students not to have good standards in responding to the era of the digital revolution[5].Therefore, research on transformational leadership related to the development of multile intelligence and efforts to overcome digital disparities in schools has not been a trend of researchers. Therefore this research needs to be done, especially in Indonesia which is developing the concept of "independent learning" and the promotion of digital literacy in which of course there are many digital gaps found among school residents. 


\subsection{Transformational Leadership}

It states that the leadership model that emphasizes the most comprehensive changes related to leadership is transformational leadership and emphasizes the emotions and values and symbolic behavior that conceptualizes the role of the leader as an effort to make all events meaningful to subordinates. This concept of leadership offers a perspective of change in the whole educational institution, so that followers realize their existence to build institutions that are ready to welcome change and even create change.Yukl suggests that transformational leadership makes followers more aware of the interests and values of work and persuades followers not to put themselves first for the sake of the organization [6]. Rivai and Mulyadi argued that transformational leaders motivate subordinates to do better with what subordinates actually expect by increasing the value of the task, with subordinates actually hoping that by increasing the value of the task by encouraging subordinates to sacrifice their own selfinterests in the aligned interests of the organization by increasing the level of subordinate needs to a better level [7].

Castanheira \& Costa say that transformational leadership has three basic functions; first, transformational leadership by sincerely serving others, empowering and inspiring followers to achieve great success, second, they charismatically lead, set vision, instill trust, believe among themselves in working with them [8]. Finally, with intellectual stimulation, they offer followers the same caliber as the the leader. Mission driven leadership is at the heart of transformational leadership. Transformational leadership is a much more complex process, its realization requires visionary and inspiring figures.The characteristics of transformational leadership, according to Baharuddin\&Umiarso , include: a) having a large vision and trusting institutions; b) Positioning themselves as the engine of change; c) dare to take risks with careful consideration; d) Providing awareness to subordinates of the importance of work results; e have confidence in the abilities of subordinates; f) flexible and open to the latest experiences; g) trying to increase motivation higher than material motivation; $h$ ) encourage subordinates to place organizational interests above personal and group interests; i) able to articulate core values (culture or tradition) to guide their behavior [9].The characteristics of transformational leadership according to Robbins and Judge are: a) Idealized Influenced Idealized influence is the behavior of leaders who provide vision and mission, generate pride, and gain respect and trust from subordinates. Idealized influence is also referred to as a charismatic leader where followers have deep faith in their leaders, feel proud to work with their leaders, and trust the capacity of their leaders in overcoming every problem .; b) Inspirational Motivation; c) Inspirational motivational is the behavior of leaders who are able to communicate high expectations, convey a shared vision in an interesting manner by using symbols to focus subordinate efforts and inspire subordinates to achieve goals that produce important progress for the organization; d) Intellectual Stimulation Intellectual stimulation is the behavior of leaders who are able to increase the intelligence of subordinates to increase their creativity and innovation, increase rationality, and solve problems carefully; d) Individualized Consideration Individualized consideration is the behavior of leaders who give personal attention, treat each subordinate individually as an individual with different needs, abilities, and aspirations, and train and give advice. Individualized consideration of transformational leadership treats each subordinate as an individual and accompanies them, monitors and needs opportunities [10].

The principles that must be created by a transformational leader according to Erik Rees are: a) simplification, the success of leadership begins with a vision that will be a mirror and a common goal [11]. The ability and skills to express a clear, practical and certainly 
transformational vision that can answer "Where are we going?" be the first thing that is important for us to implement; b) Motivation, the ability to get commitment from everyone involved with the vision that has been explained is the second thing we do. When transformational leaders can create a synergy within the organization, it means they should be able to optimize, motivate and energize each of their followers. Practically it can be in the form of tasks and work that are truly challenging and provide opportunities for them to be involved in a creative process both in terms of giving suggestions or making decisions in solving problems, so this will also provide added value for themselves; c) Facilitation, in terms of the ability to effectively facilitate learning that takes place within the organization institutionally, in groups, or individually. This will have an impact on increasing the intellectual capital of everyone involved in it; d) Innovation, is the ability to boldly and responsibly make changes when needed and be demanded by changes that occur. In an effective and efficient educational organization everyone involved needs to anticipate changes and they should not be afraid of those changes. In certain cases transformational leaders need to be quick to respond to change without compromising trust in the work team that has been built; e) mobilization, which is the mobilization of all available resources to complement and strengthen everyone involved in achieving the vision and goals. Transformational leaders will always seek followers who are full of responsibility; f) Standby, which is the ability to always be ready to learn about themselves and welcome change with a positive new paradigm; g) Determination, which is determined to be always round to the end, determined to complete something well and completely. For this reason, it is also necessary to support the development of spiritual, emotional, physical and commitment disciplines.

Guidelines for Transformational Leadership according to Yukl, in the form of tentative guidelines which are work steps that need to be implemented by leaders who are trying to inspire and motivate followers / subordinates [6]. Among the transformational leadership guidelines include: a) stating a clear and attractive vision; b) explain how the vision can be achieved; c) act confidentially and optimistically. Subordinates will believe in a vision if the leader shows confidence and conviction and is optimistic that the group will succeed in achieving its vision; d) show confidence in followers; e) use dramatic and symbolic actions to emphasize important values; f) lead by example; g) give people authority to achieve that vision [12].Based on the description that good leadership is believed to be able to achieve the desired targets through the process of influencing, harmonizing and increasing the potential and sub-resources of the organization. A leader must have plans that will be achieved together. To achieve that target, a leader must be able to build togetherness by influencing, directing, mobilizing and empowering its members to achieve common goals [13]. Of all the efforts made, the target of transformational leadership is to build togetherness both leaders and followers in an organization.Transformational leadership that does not pay attention to local culture encountered many obstacles in the field. The school's vision, mission, programs, and goals are not necessarily successful because of the greatness of the principal in formulating them. Implementation of theories about transformational leadership in schools often has a gap between expectations and reality. Pseudo obedience and pretense by school residents to the principal often occur, so that there are only pseudo-activities to pursue mere formality. This could be possible due to the principal's insensitivity to local wisdom. Therefore it is necessary to conduct research that links this transitional leadership with local wisdom. 


\subsection{Local Wisdom}

In the era of the Industrial Revolution 4.0 or the digital revolution, the nations of the world competed to develop the nation's human resources to become a developed nation. Several perspectives and studies show that a developed nation is a nation that has a strong character. The strong character in question is a character that has authentic cultural values that are in harmony with the local local community (local wisdom)[14]. But along with globalization, not a few people are affected or imitating the culture of other nations, which is uncertain whether the culture is in accordance with the characteristics and personality of a nation. If we view Japan as a developed country, they have succeeded in forming a developed nation because they hold fast and respect the culture that was explored from the spirit of their own ancestors that we are familiar with (bushido). In addition there is more, South Korea is a developed nation also because it managed to preserve the culture of its ancestors called the spirit of semaulundong, even their culture can influence other nations so that many imitating and exemplifying South Korean culture.

The progress achieved by various nations indicates that the development of the character of a nation cannot be separated from cultural aspects that are in accordance with the characteristics of the nation's own people [15]. Culture that is extracted from local wisdom is not used as an obstacle in the progress of the digital age, however, the values of local wisdom can be a cultural filter and extraordinary transformational power in achieving the glory of the nation. Local wisdom in a foreign language is local wisdom, local knowledge, local genius [16]. Local wisdom itself can be interpreted as a thought about life based on clear reasoning, good reasoning, and containing positive things. In terms of local wisdom can be interpreted as the work of reason, deep feelings, character, mannerisms, and suggestions for human glory. Mastery of local wisdom will carry their souls to be more virtuous. Naritoom formulates local wisdom with the definition, "local wisdom is the knowledge that is discovered or acquired by local people through the accumulation of experiences in trials and integrated with the understanding of surrounding nature and culture [17]. Local wisdom is dynamic by the function of created local wisdom and connected to the global situation "[18]. The scope of local wisdom is a broad and comprehensive phenomenon. The scope of local wisdom is quite numerous and varied so that it is difficult to be limited by space. Traditional wisdom and wisdom are now different from local wisdom. Local wisdom places more emphasis on the place and locality of the wisdom so that it does not have to be a wisdom that has been passed down from generation to generation. Local wisdom can be wisdom that has recently emerged in a community as a result of its interaction with the natural environment and its interactions with other communities and cultures. Therefore, local wisdom is not always traditional because it can encompass present-day wisdom, and because of that it can also be broader in meaning than traditional wisdom. To distinguish local wisdom that has just emerged from local wisdom that has long been known by the community, the terms "current wisdom", "new wisdom" or "contemporary wisdom" can be used. Traditional wisdom can be called "wisdom.

\subsection{Multiple Intelegences}

Gardner introduced the theory of multiple intelligence (MI) in Indonesia's book, Frames of Mind, published in 1983. Arriving in his theory, Gardner combined the empirical findings of hundreds of studies from various scientific disciplines (see extensive bibliography in the original book). Although he belongs to psychometric and experimental psychology, what he does does not limit his support base to this discipline. In contrast, MI theory also includes 
cognitive and developmental psychology, differential psychology, neuroscience studies of anthropology, and culture [19].

Some aspects of Multiple Intelligence include: (1) verbal-linguistic intelligence and learning process, focusing on speaking, reading, and writing; (2) logical-mathematical intelligence, focus on teaching logic, mathematical processes, working with numbers, and sorting; (3) kinesthetic intelligence, with a focus on drama, creative movement, dance, manipulative, class games, physical education, and sports; (4) visual-spatial intelligence, with a focus on pictorial representations, flowcharts, visualizations, board and card games, architecture, and visual arts; (5) musical intelligence, focus on singing, music notation, curriculum songs, and musical instruments; (6) interpersonal intelligence, focus on positive interpersonal environments, conflict management, learning through services, respecting differences, various perspectives, problem solving, and multicultural education; (7) intrapersonal intelligence, focus on self-esteem, goal setting, thinking skills, emotional expression, and independent learning [20].

\section{Digital Gap}

The dynamics of people's lives in the era of the industrial revolution 4.0 underwent rapid transformation. But the lack of preparedness and skills of the people in Indonesia as a developing country is a challenge to respond to the industrial revolution 4.0 in shaping awareness as a global citizen. There are some facts that some Indonesian citizens, both generations born before the development of digital technology (digital immigrants) and generations born after the development of technology (digital native), show that they do not yet have reliability, both digital science and the practice of all life activities in the revolutionary era this. From the old generation generation, they were less reliable in using or operating technological devices because they were small from technology literacy, the internet, smartphones and various other technological products [21]. Meanwhile, from the millennial generation, they are already familiar with technology products, because from a small technology device has been introduced, but still weak in the ability to relate and compensate for technological progress with a limited global scope. This is because the Indonesian people have obstacles in the mastery of English so that they become obstacles in communication and collaboration across nations. The weakness of English in Indonesia in general is caused by the people not accustomed to using English from childhood. The data states that in Indonesia as a large country having various types of languages, there are around more than 700 different regional languages with different dialects (Marcellino, 2008) and they prefer to use their own regional languages and Indonesian as a daily unifying language rather than using English which is a less familiar language [22].

Research on transformational leadership in schools that usually leads to: motivation, team work development, teacher and staff performance improvement, school quality improvement, school culture development, student achievement improvement, and school rankings. Research on transformational leadership with local wisdom that leads to the development of multiple intelligence and efforts to overcome digital disparities in schools has not been found. Therefore this research becomes very important and has an element of research novelty. 


\section{Research Method}

Qualitative approach is used in this study because it is associated with qualitative data, in the form of words, sentences, attitudes, behaviors. This research was conducted at SD Muhammadiyah 1 Surakarta, under natural conditions. Researchers act as key instruments, are descriptive, emphasize processes rather than products or outcomes, conduct data analysis inductively, emphasize meaning. This research emphasizes understanding and meaning, is closely related to certain values, emphasizes process rather than measurement, describing, interpreting, giving meaning and not enough with mere explanation. This research uses a case study design. Data collection uses in-depth interviews, observation, and documentation. With 12 respondent Researchers as a key instrument because it can directly adjust to respond to interactions that occur in the subject, so researchers can maintain wholeness, develop knowledge base, process information immediately, and can utilize to investigate special or special responses. The presence of researchers as a primary tool is sometimes faced with psychological problems. Therefore, researchers need to pay attention to the ethical principles of research.

Research data sources are principals, teachers, employees, and students. The selection of informants is done purposively based on the aims and objectives of the study. Purposive is based on consideration of the ability of informants to provide information needed in research. The validity of the data is very important in research, because it will guarantee the reliability of the data in solving the problem under study. In qualitative research, the researcher is the main instrument, therefore the validity and reliability of the instrument is carried out by checking the credibility and auditing of the data [23]. In qualitative research, the data validity criteria are carried out by checking / testing four criteria, namely the degree of trust (credibility), tranferability, dependability, and confirmability.Data analysis using interactive model analysis includes stages: 1) data collection; 2) data reduction; 3) data presentation; and 4) verification. The analysis is carried out continuously from the beginning of the data collection until the data of the complete research is completely obtained. The analysis process takes place interactively, which tests between components in a cycle that lasts for a long time, in order to obtain the results of a truly thorough and in-depth explanation.

\section{Results And Discussion}

The leadership of the principal of SD Muhammadiyah 1 Surakarta fulfills all the transformational leadership indicators as stated by Robbins and Judge in Rahmias follows: a) Idealized Influenced; b) Inspirational Motivation; c) Intellectual Stimulation; d) Individualized Consideration [24]. In addition, the principal's leadership also applies the principles of local wisdom. The results of the interactive analysis based on in-depth interview data, observations, and documentation are presented in the following table 1.

Table 1. The results of the interactive analysis based on in-depth interview data, observations, and documentation

\begin{tabular}{llll}
\hline $\begin{array}{c}\text { The element } \\
\text { under study }\end{array}$ & Indicator & Description & $\begin{array}{c}\text { Positive } \\
\text { response from } \\
\text { subordinates }\end{array}$ \\
\hline $\begin{array}{l}\text { Transformation } \\
\text { leadership based }\end{array}$ & $\begin{array}{c}\text { Idealized } \\
\text { Influenced }\end{array}$ & $\begin{array}{l}\text { a. To explain the vision and mission clearly, wasis, polite } \\
\text { language, respect the audience, respond to questions }\end{array}$ & $94,05 \%$ \\
\hline
\end{tabular}




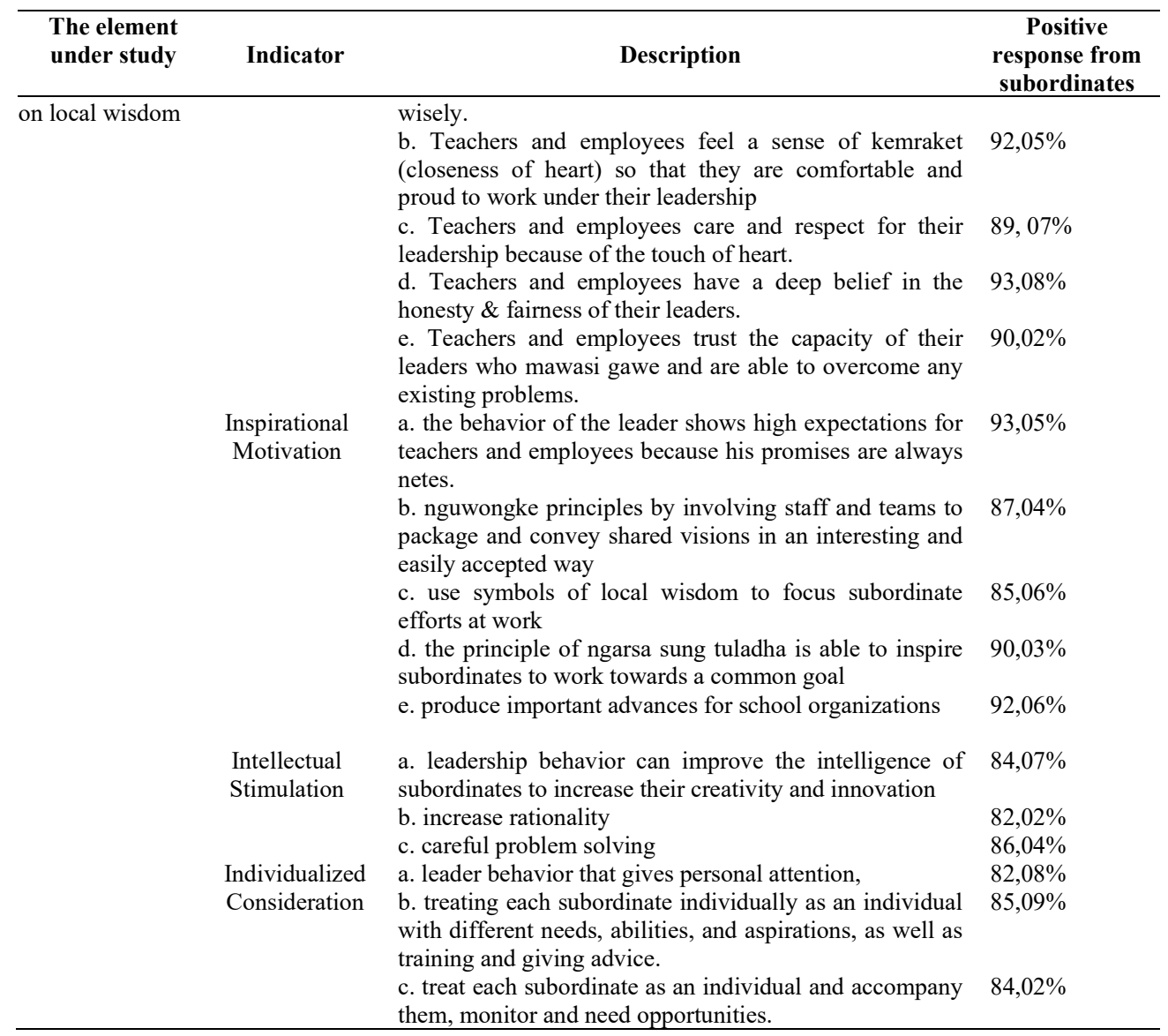

The transformational leadership of the local wisdom school principal at SD Muhammadiyah 1 Surakarta is characterized by the following indicators:

a) Idealized Influenced: a) explain the vision and mission clearly, wasis, polite language, respect the audience, respond to questions wisely; b) Teachers and employees feel a sense of kemraket (closeness of heart) so that they are comfortable and proud to work under their leadership; c) Teachers and employees care and respect for their leadership because of the touch of heart; d) Teachers and employees have a deep belief in the honesty \& fairness of their leaders; e) Teachers and employees trust the capacity of the leader who mawasi gawe and able to overcome any existing problems.

b) Intellectual Stimulation: a) the behavior of the leader shows high expectations for teachers and employees because his promises are always netes; $b$ ) the guiding principle by involving staff and teams to package and share a shared vision that is interesting and easily accepted; c) use local wisdom symbols to focus subordinate efforts at work; d) the principle of inviting sung tuladha is able to inspire subordinates to work towards a common goal; e) produce important advances for school organizations.

c) Intellectual Stimulation: a) the behavior of leaders is able to increase the intelligence of subordinates to increase their creativity and innovation; b) increase rationality; c) careful problem solving. 
d) Individualized Consideration: a) leader behavior that gives personal attention; b) treat each subordinate individually as an individual with different needs, abilities and aspirations, as well as training and giving advice; c) treat each subordinate as an individual and accompany them, monitor and need opportunities.

The results of this study are in line with research by In-Sue Oh, Wang Courtright, Amy and Colbertstating that transformational leadership is positively related to follower performance at the level of individuals with certain types of criteria, with a stronger relationship to contextual performance than task performance through study settings [25]. Sandell Kylestates that the interrelationship of the duties of followers in transformational leadership can mediate the relationship between what is considered transformational leadership and task performance [26]. With a better understanding of how leaders build engagement and drive performance in specific tasks, organizations can take advantage of the influence of leader interactions with followers every day.

Ahmad, Abbas, Latif, and Rasheed stated that there was a significant relationship between transformational leadership and employee motivation [27]. In line with research by Abid Nabila, Farooqi and Yasir Aftab which states that transformational leadership has a significant positive relationship with organizational citizenship behavior and employee performance. Felix state the path analysis of the structural model shows a statistically significant relationship between cognitive moral development (CMD) and transformational leadership style (TFL) $(\mathrm{B}=0.120, \mathrm{t}=1.286, \mathrm{P}<0.10)$.

Rawung Ficke H., Wuryaningrat Nikolas F and Elvinita Lenny E said that according to empirical evidence of transformational leadership, especially for individual considerations and dimensions of individual inspiration, positively impacted knowledge sharing activities [28]. Strukan, Nikolic, \& Sefic state that transformational leadership has a positive impact on achieving high-level financial performance and developing new products [29]. Dick Hinojosa, Yun Sun, and Wheeler state that transformational leadership is strongly related to transactional leadership and the avoidance of passive leadership and negatively related to transactional and transformational leadership [30].

Table 2. Transformational leadership in developing multiple intelligences is presented in the following table.

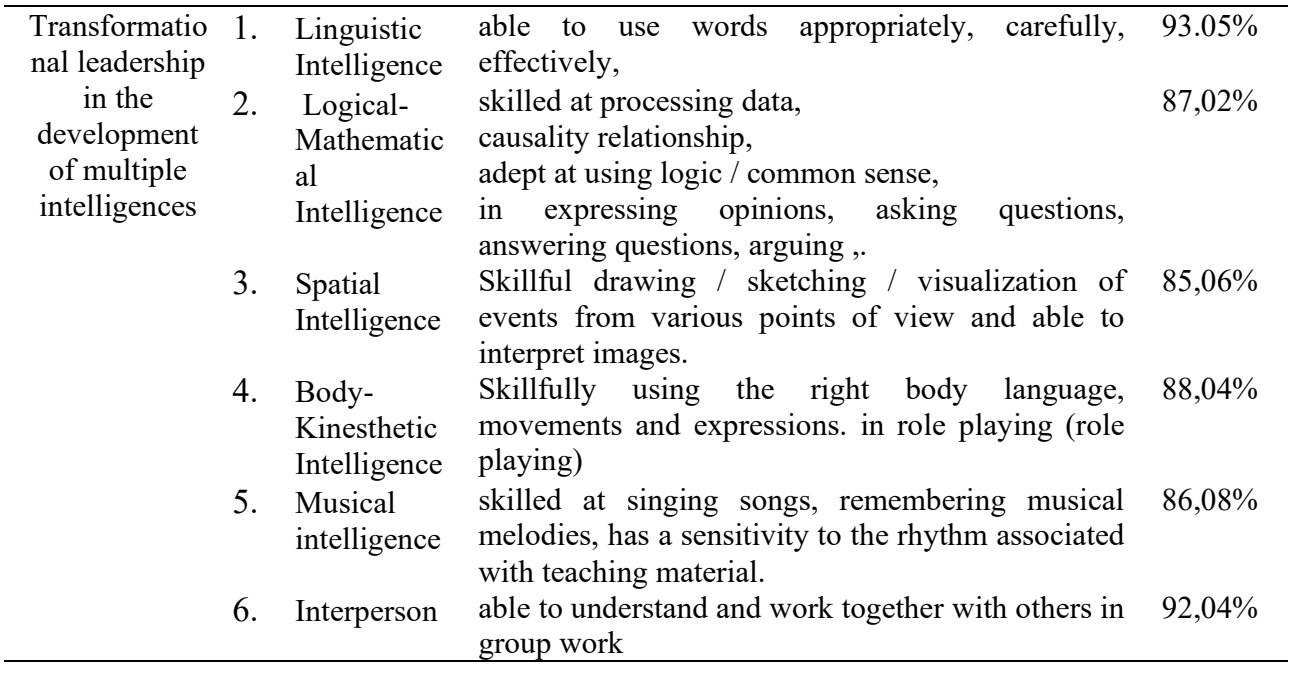


al

intelligence

7. Intraperson Able to do self-introspection, realize and al responsibility for mistakes, know the advantages

$90,06 \%$ Intelligence and disadvantages

8. Naturalist able to maintain the existence of the natural Intelligence surroundings, flora, fauna, as well as having the spirit to preserve.

Moolennar, Daly. and Sleegers state that transformational leadership has led to a promising approach in increasing demands for developing and implementing innovations in schools [31]. Balyer states that principals demonstrate the high behavioral practices of transformational leaders in idealized influences, inspirational motivation, individualized consideration and intellectual stimulation [32]. Datche states that both transformational leadership and employee involvement are significantly related to organizational performance in SOEs in Kenya. Three of the four dimensions of transformational leadership; inspirational motivation (although weak), intellectual stimulation and individualized consideration are significantly related to both employee involvement and organizational performance. Idealized influence, however, is negatively related to both [33].

LukelShifayasfina states that transformational leadership of organizational citizenship behavior and organizational commitment positively and significantly affect employee performance, the results of the study also prove that there are simultaneously positive and significant influences on transformational leadership variables, organzational citizenship behavior and employee performance commitment [34]. Wiley \& Sons states the quality of transformational leadership of a leader shows the role relationship between team conditions and performance [35].

Table 3. Transformational leadership in overcoming digital dividepresented in the following table.

\begin{tabular}{ll} 
1. between teachers & $95,03 \%$ \\
2. between tendons & $92,07 \%$ \\
3. between teacher and tendik & $89,02 \%$ \\
4. between leaders & $98,02 \%$ \\
5. between leaders and teachers & $96,05 \%$ \\
6. between leaders with tendons & $90,08 \%$ \\
7. between students & $86,04 \%$ \\
8. between students and teachers & $84,07 \%$ \\
9. between students with tendons & $88,09 \%$ \\
\hline
\end{tabular}

Jovanovic Dragana and Ciric Marina stated that transformational leadership is the most appropriate leadership to guide students in school conditions [36]. White Sarah K states transformational leadership is a leadership model in which leaders encourage, inspire and motivate employees to innovate and create changes that will help grow and shape future success in the company [37]. This success was achieved by setting an example at the executive level through a strong corporate culture of employee ownership and independence in the workplace. Paracha, Qamar, Mirza, \& Waqas state that both transactional and transformational leadership are positively related to employee performance, however transactional leadership is more significant than transformational [38]. Another important finding is that there is no mediating role for job satisfaction among transactional leadership. But this mediates with transformational leadership and employee performance.Jennifer Gunn said transformational leadership in schools is when a leader empowers members in the learning community to improve from within. Transformational leaders not only run schools, only maintain existence, such leaders make things better through collaboration between school members and stakeholders. 


\section{Conclusion}

Principal leadership meets all transformational leadership indicators, characterized by: Idealized Influenced; Inspirational Motivation; Intellectual Stimulation; Individualized Consideration that applies the principles of local wisdom.Transformational leadership in developing multiple intelligence includes: Word Smart, Number smart, Picture Smart, Body Smart, Music Smart, People Smart, Self Smart, Nature Smart.Transformational leadership in overcoming digital divide includes gaps: between teachers, between education staff, between teachers and education staff, between leaders, between leaders and teachers, between leaders and education staff, between students, between students and teachers, between students and staff education.

\section{References}

[1] Yunita F-K. The role of the principal' $\mathrm{s}$ instructional leadership at schools in Indonesia. 2015;(December):92.

[2] $\mathrm{O}$

GS. No 主観的健康感を中心とした在宅高齢者における健康関連指標に関する共分散構造分析Ti tle. Society [Internet]. 2018;1:14-8. Available from: https://movisa.org.mx/images/NoBS_Report.pdf

[3] Furuholt B, Wahid F. E-government challenges and the role of political leadership in Indonesia: The case of Sragen. Proc Annu Hawaii Int Conf Syst Sci. 2008;1-10.

[4] Pranesh V, Palanichamy K, Saidat O, Peter N. Lack of dynamic leadership skills and human failure contribution analysis to manage risk in deep water horizon oil platform. Saf Sci [Internet]. 2017;92:85-93. Available from: http://dx.doi.org/10.1016/j.ssci.2016.09.013

[5] Rachmawati, Ekowiyanti MI. The role of Indonesian School Librarian in increasing students' literacy skills in digital age. IASL Annu Conf Proc. 2016;

[6] Yukl, Gary. (2011). Kepemimpinan Dalam OrganisasiEdisi Kelima.Jakarta: Rineka Cipta

[7] Mulyadi dan Rivai. (2009). Manajemen Sumber Daya Manusia. Jakarta: Bumi Aksara.

[8] Castanheira, P. \& Costa, J. A. (2011)."In search of transformational leadership: A (Meta) analysis focused on the Portuguese reality". Procedia Social and Behavioral Sciences, 15 (2011), 2012-2015.Diakses pada 02-02-2019

[9] Baharudin dan Umiarso. (2012). Kepemimpinan Pendidikan Islam.Jogjakarta : Ar-Ruzz Media.

[10] Rahmi, Sri. (2014).Kepemimpinan Transformasional dan Budaya Organisasi.Jakarta : Mitra Wacana

[11] Erik Rees.(2001). "Seven Principles of Transformational Leadership -- Creating A Synergy of

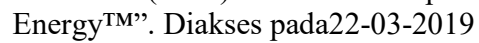

[12] Felix ChikeluOkey, Ahmad AbdHalim\&Arshad Rosita.(2015). e-Journal of the Social."Ethical Reasoning and Transformational Leadership Style in the Nigerian Public Sector".Volume 32015.Diakses pada 24-02-2019

[13] Hacker,Stephen K. (2009). "Transformational Leadership:Creating Step-Functional Change". Diakses pada 22-01-2019

[14] Wagiran. Pengembangan karakter berbasis kearifan lokal. J Pendidik Karakter. 2012;II(3):329 39.

[15] Cheng YC. Fostering local knowledge and human development in globalization of education. Int J Educ Manag [Internet].2004;18(1):7-24. Available from: http://search.ebscohost.com/login.aspx?direct $=$ true $\& \mathrm{db}=$ eue $\& A N=56508380 \&$ site $=$ ehostlive\%5Cnhttp://www.emeraldinsight.com/doi/pdfplus/10.1108/09513540410512109

[16]Ratana-Ubol A, Henschke JA. Cultural Learning Processes through Local Wisdom: A Case Study on Adult and LifelongLearning in Thailand. Int J Adult Vocat Educ Technol. 2015;6(2):41-60.

[17] Imbroscio DL, Williamson T, Alperovitz G. Local policy responses to globalization: Place-based ownership models of economic enterprise. Policy Stud J. 2003;31(1):31-52. 
[18] Sumiati E, Hufad E. Study of Indigenous Peoples Empowerment Model in Cireundeu Village. 2016;73-6.

[19] Gardner H, Moran S. The science of multiple intelligences theory: A response to lynn Waterhouse. Educ Psychol. 2006;41(4):227-32.

[20] Butcher MF, Saltonstall M, Bickel S, Brandel R. Northern Arizona University. New Dir Student Serv. 2009;2009(127):45-52.

[21] Nurhayanto P, Wildan D. Transformasi Nilai-Nilai Kearifan Lokal Masyarakat Adat Cireundeu. Sosietas. 2016;6(1).

[22] Lamb M, education HC-I journal of bilingual, 2008 undefined. Literacy in English and the transformation of self and society in post-Soeharto Indonesia. Taylor Fr [Internet]. [cited 2018 Aug 24]; Available from: https://www.tandfonline.com/doi/abs/10.2167/beb493.0

[23] Guba, E. G., \& Lincoln, Y. S. (1994). Competing paradigms in qualitative research. In N. K. Denzin \& Y. S. Lincoln (Eds.), Hand book of qualitative reseach (1 ed., pp. 105-117). Thousands Oaks, CA: Sage

[24] Rahmi, Sri. (2014).Kepemimpinan Transformasional dan Budaya Organisasi.Jakarta : Mitra Wacana

[25] In-Sue Oh, Gang Wang., Courtright,Stephen. H., and Colbert, Amy E. (2011).Group and Organization Management,"Transformational Leadership and Performance across Creteria and Levels: A Meta-analytic Review of 25 Years of Research,”. Volume-2. Diakses pada 22-01-2019

[26] Sandell, Kyle .(2012).Thesis. Colorado State University"Transformational Leadership, Engagement, and Performance : A New Perspective".Diakses pada 22-03-2019

[27] Ahmad, Farid., Abbas, Tasawar., Latif, Shahid., and Rasheed, Abdul (2014) Journal of Management Policies and Practices"Impact of Transformational Leadership on Employee Motivation in Telecommunication Sector."Volume 2. Diakses pada 29-02-2019

[28] Rawung Ficke H., Nikolas F. Wuryaningrat and Elvinita Lenny E. ( 2015).Asian Academy of Management Journal."The Influence of Transformasional dan Transactional Leadership on Knowledge Sharing: an Empirical Study on Small and Medium Business in Indonesia." Volume20.Diakses pada 02-03-2019

[29] Strukan Edin, Nikolic Milan, Sefic Senad.(2017). Utjecaj Transformacjskog Lidertva Na Poslovne Performance "Impact of Transformational Leadership on Business Performance." Volume 10.Diakses pada 21-03-2019

[30] Dick, Rhonda., Hinojosa, Barbara Baggerly., Yun Sun, and Wheeler, Carol. 2017. Journal of Education and Social Development."Leadership in On line Education : Does it Matter?"http://www.ibii-us.org/Journals/JESD/Volume 4-2017. Diakses pada 22-02-2019

[31] Moolennar, Neinke M., Daly, Alan J., and Sleegers, Peter J.C. (2010).Educational Administration Quarterly. "Occupying the Principal Position: Examining Relationships betweenTransformational Leadership, Social Network Position, and Schools'Innovative Climate".Diakses pada 22-02-2019

[32] Balyer, Aydin. (2012).International Online Journal of Educational Sciences."Transformational Leadership Behaviors of School Principals: A Qualitative Research Based on Teachers' Perceptions".Volume 3. Diakses pada 04-02-2019

[33] Datche Evelyn Awuor. (2015). Dessertation. "Influence of Transformational Leadership on OrganizationalPerformance of State Corporations in Kenya."Diakses pada 22-02-2019

[34] Lukel, Shifayasfina. (2016).Thesis.Universitas Lampung. "Pengaruh Kepemimpinan Transformasional, Organizational Citizenship Behavior dan Komitmen Organisasional Terhadap Kinerja Karyawan PT. Bank Rakyat Indonesia (Persero) TBK Kantor Cabang Pringsewu."Diakses pada 20-02-2019

[35] Wiley \& Sons. (2018).Project Management Journal Linking Team Condition and Team Performance.“ATransformational Leadership Approach.”Diakses pada 22-03-2019

[36] JovanovicDragana, CiricMarina. 2016. World LUMENCongress."Benefits of Transformational Leadership in the Context of Education.'Diakses pada 12-02-2019 
[37] White Sarah K. .(2018) "What is transformational leadership? A model for motivating innovation.”.https://www.cio.com/article/3257184/what-is-transformational-leadership-a-modelfor-motivating-innovation.html. Diakses pada 29-03-2019

[38] Paracha Umer, Qamar Adnan, Mirza Anam, \& Waqas Inam-ul-Hassan (2012). Global Journal of management and Business Research."Impact of Leadership Style (Transformational \& Transactional Leadership) On Employee Performance \& Mediating Role of Job Satisfaction Study of Private School (Educator) In Pakistan.”Volome 12. Diakses pada 22-02-2019 